\title{
Literature review: implementation of Musharakah Mutanaqisah partnership over the world
}

\author{
Wiwin Juliyanti ${ }^{1}$, Yohanes K. Wibowo ${ }^{2}$ \\ Magister Akuntansi, FEB Universitas Sebelas Maret ${ }^{1,2}$ \\ wiwinjuliyanti22@gmail.com ${ }^{1}$, jahesweet@ gmail.com ${ }^{2}$
}

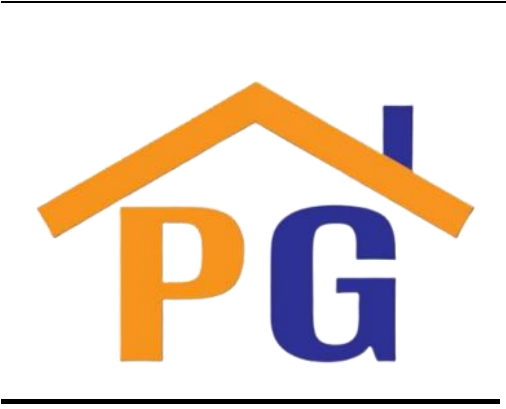

Riwayat Artikel

Diterima pada 12 Januari 2021

Revisi 1 pada 14 Januari 2021

Revisi 2 pada 1 Februari 2021

Disetujui pada 4 Februari 2021

\begin{abstract}
Purpose: This study aimed to determine the implementation of Musharakah Mutanaqisah.
\end{abstract}

Research methodology: This research method was a literature study with data obtained from previous research and theories relevant to the research topic.

Results: The research results show that Musharakah Mutanaqisah in the two countries still needs to be encouraged for its development, because Murabahah still dominates it, Ba'i, ijarah and others financing, the results of the study also concluded that the implementation of Musharakah Mutanaqisah is equally an alternative in property financing in Malaysia, and homeownership loans in Indonesia.

Limitation: This research only examined the application of MMP in Southeast Asia.

Contribution: Findings contribute that internationally, accounting for Musharakah Mutanaqisah refers to IFRS and FAS. In Malaysia, the regulations governing the accounting for Musharakah Mutanaqisah are regulated in the Malaysian Financial Reporting Standards (MFRS). ). In Indonesia, the regulations governing the accounting for Musharakah Mutanaqisah are not yet available, so they are still regulated in PSAK No. 106 (Musharakah Akad).

Keywords: Musharakah Mutanaqisah partnership, Islamic bank, Sharia accounting

How to cite: Juliyanti, W., \& Wibowo, Y. K. (2021). Literature review: implementation of Musharakah Mutanaqisah partnership over the world. Bukhori: Jurnal Ekonomi dan Keuangan Islam, $1(1), 1-10$.

\section{Introduction}

The Islamic finance industry continues to experience development. Unofficially, sharia finance has been around since 1992 by establishing a financing business entity that implements profit-sharing practices in its operational practices and contract system (Maulida, 2020). Currently, Islamic bank products are increasing, so many Islamic banks are offering their services. This can be seen from the multi-contract product. The multi-contract product is known as a hybrid contract, where one of the hybrid contracts being discussed in this study is the Musharakah Mutanaqisah contract (Sarwedhie \& Suprayogi, 2013).

One of the applications of hybrid contracts in Islamic banks is the property financing product with the Musharakah Mutanaqisah contract. This contract is still relatively new in property financing, so not all Islamic banks implement the contract (Rohmi, 2015). In the data contained in the Financial Services Authority (OJK) as of June 2020 in Indonesia the percentage of the largest amount of financing is the Murabahah contract, namely $44.87 \%$, while the Musharakah contract is in the second position, namely $25.81 \%$ (Hendarsyah et al., 2020). Another financing contract introduced was the Musharakah Mutanaqisah financing, also known as a downward partnership. This contract is a better alternative to 
Islamic financing (Sabri \& Ahmad, 2014). In implementing the Musharakah Mutanaqisah contract, the bank can also benefit from increasing the number of consumer financing portfolios to balance funding and lending funds (Rohmi, 2015).

In the current practice of Musharakah Mutanaqisah, there are two accounting standards used, namely International Financial Reporting Standards (IFRS) and The Financial Accounting Standards (FAS) (Muhamad Sori, 2017). In Indonesia, the regulations governing the Musharakah Mutanaqisah contract's accounting treatment are still not available, and there are no specific regulations in the PSAK governing the Musharakah Mutanaqisah contract. The Musharakah Mutanaqisah contract still refers to the Musharakah contract (Sarwedhie \& Suprayogi, 2013). Initially, the credit was good and quite helpful for customers. In this case, it not only helps customers, but also the developer (who in this case is the house builder) feels helped by the product. The bank indirectly participates in marketing houses that have been or will be built by the developer. In Indonesia, two systems are run by bank financial institutions, namely one that uses the conventional system, and some that use the sharia system. Conventional banks in their operations still use interest instruments, while Islamic banks do not apply interest instruments, but rather with profit-sharing instruments or commonly referred to as Profit and Loss Sharing.

As the bank operates, it turns out that the credit does not always help the community, but sometimes it can be burdensome for the community. This is evidenced by not a few who experience problems (in repayment or when they want to pay in installments), when they have bought or used credit facilities offered by financial institutions (especially banks). Although many also feel helped by the homeownership credit. However, this still needs attention because if a problem is left unchecked, it will cause a threat to the bank and customers over time. In practice, banks when offering credit products (financing) in the provision of various houses. If conventional banks use conventional KPR (homeownership credit) products which with all the conditions still use interest instruments, while in Islamic banks the model of contracts offered varies, some of them use the Ijarah Muntahiya Bit Tamlik (IMBT) contract, which is a lease that ends in moving. ownership of goods), some use a Murabahah (sale and purchase) contract, some use a Musharakah Mutanaqishah contract.

From the information above, it can be is known the problem that emerged, namely that in offering Islamic banks financing products for home ownership there is not yet a contract model. This gives rise to presebased on the background of the problem, the researcher wants to know how the implementation of the Mutanaqisah Musharaka financing implementation compares in several countries. The Musharakah Mutanaqisah contract is widely used in various countries as a source of sharia housing financing, which prohibits interest involvement. However, in its implementation, there are still many criticisms from the scholars regarding the suitability of sharia principles applied in Musharakah mutanaqah products (Loke et al., 2017).

\section{Literature review and hypotheses development}

\subsection{Musharakah Mutanaqisah}

Musharakah Mutanaqisah is a derivative product of the Musharakah contract, namely a cooperation contract made by both parties or more for the ownership of an item or asset. In this cooperation, the ownership rights of one party will decrease, and on the other hand, one party's ownership rights will increase. The transfer of ownership occurs through a payment mechanism for other ownership rights (Waluyo, 2014). Musharakah Mutanaqisah (MMQ) is a product development of a profit-sharing based product, namely the Musharakah contract. Musharakah Mutanaqisah can be applied as a sharia banking financing product based on the principle of syirkah 'inan, where the portion of capital (Hishshah) of one of the syarik (partners), namely the bank is reduced due to a gradual commercial purchase or transfer (naqlul hishshah bil' iwadh mutanaqisah) to sharik ( partners), namely customers (OJK, 2016). The amount of Islamic bank capital is getting smaller or decreasing, inversely proportional to the amount of customer capital increasing due to instalment payments every month. At the end of the financing period, $100 \%$ of the bank's capital has been taken over by the customer so that the ownership of the house is transferred to the name of the customer. 


\subsection{Risk of Musharaka Mutanaqisah financing}

The risks involved in financing musharaka include four things, namely (Hosen, 2016):

1) Ownership Risk

In the financing of the Musharakah Mutanaqisah, the status of ownership of the goods is still joint ownership between the bank and the customer. This is a consequence of financing the Musharakah Mutanaqisah.

2) Regulatory Risk

In the practice of Musharakah Mutanaqisah, the financing of goods is bound by the applicable regulations. One of the regulations governing Musharakah Mutanaqisah is imposing Value-Added Tax (VAT) on ownership of goods. The imposition of VAT is based on Law No. 18 of 2000, which is an amendment to Law No. 8 of 1983.

3) Market Risk

Market conditions will cause fluctuations in the price of an item. Regional differences in the cooperation of Musharakah Mutanaqisah cause price differences so that the bank cannot equalize prices, besides that the financing of ownership of goods with the Musharakah Mutanaqisah scheme is a form of joint purchase between Islamic banks and customers.

4) Credit Risk (Financing)

The process of financing Musharakah Mutanaqisah, which is carried out in instalments every month, will cause credit risk. There may be wan achievement from the customer, where the customer cannot fulfil his obligations every month.

\subsection{Musharakah Mutanaqisah mechanism}

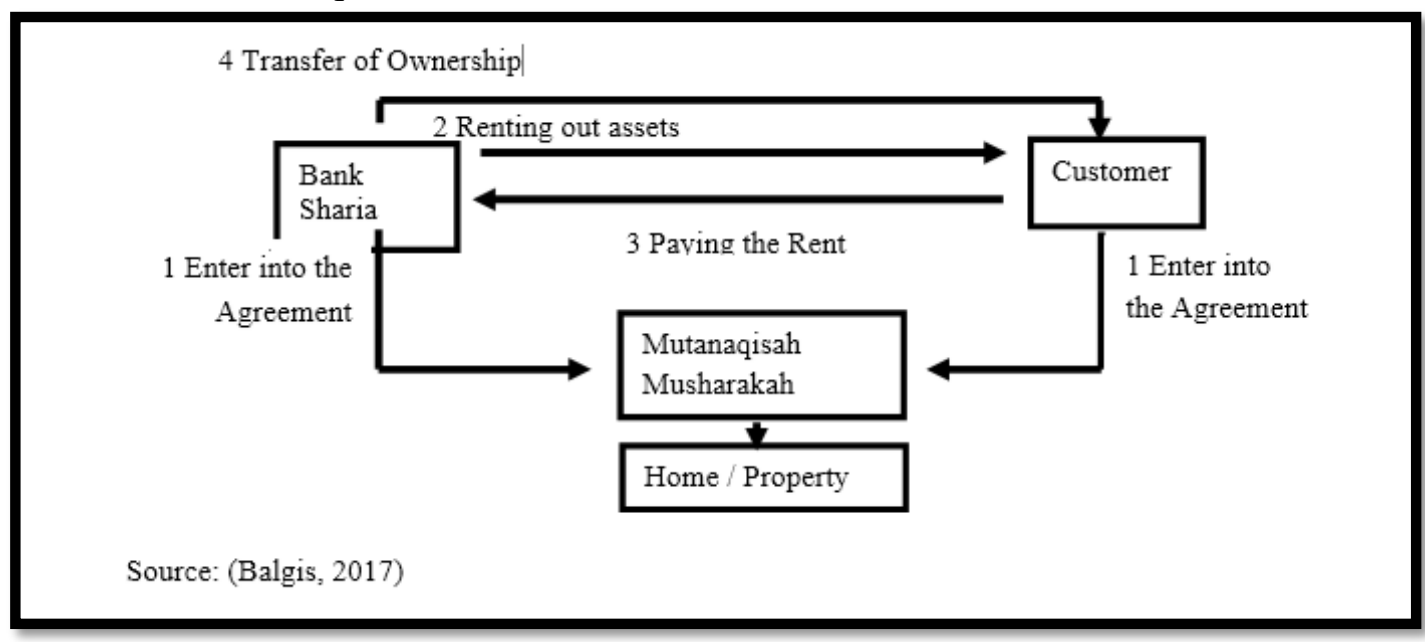

Figure 2. Musharakah Mutanaqisah financing scheme

In research conducted by Asadov, Muhamad Sori, Mohamad Ramadilli, Anwer, \& Shamsudheen (2018) It is explained that the agreement or agreement made by the bank and the customer with the Musharakah Mutanaqisah contract must go through several stages, namely:

1) Both parties (the customer and the bank) cooperate in managing capital to buy a property or house.

2) Property or house becomes joint property between the bank and the customer based on the ratio of payment for purchasing the property or house.

3) The bank begins to share and agree on profits and losses to customers (by means of which the customer must pay a monthly rent to the bank) with a predetermined period.

4) The customer gradually purchased the homeownership owned by the bank during that period.

5) Furthermore, ownership owned by the bank transfers to the customer, and the customer has full ownership of the property. 


\subsection{The advantages and disadvantages of $M M Q$}

The weaknesses of the Musharakah Mutanaqisah contract are as follows (Smolo \& Kabir Hassan, 2011):

1) Musharakah Mutanaqisah is seen as less attractive to banks because it will bring lower profits for Islamic banking.

2) The basic theory of economics is that the price of a product or service decreases, and the demand for services increases. Therefore, the banks will lose some of their profits if they apply the Musharakah Mutanaqisah financing.

3) Rental rates change from time to time and are determined by the property's location (in the case of home financing). Estimating change is not an easy thing for banks. Simultaneously, as the increase in rental rates it may be difficult for the bank to ask the customer that he now has to pay a higher rent from the property.

4) Legal stipulation is needed, especially concerning the tax structure. This suggests that laws must be in place to ensure that customers are not taxed twice for the same property.

5) Laws regarding land and laws relating to Islamic banking and finance may have to be changed to allow banks to become property owners.

\section{Research methodology}

. This study used a qualitative approach, data collection techniques which are defined as the most important step in research to obtain data in this study are literature studies. Library research has special characteristics such as: dealing directly with text, researchers dealing directly with existing sources in the library, researchers obtaining data from secondary sources and not from primary field data, and the condition of the data in the library study is not limited by space and time. The research method in this research is literature study, where the research results and the data obtained in this article are the results of previous research reviewed by the researcher. This research's scope is about how the implementation and practice of Musharakah Mutanaqisah in two countries, namely Malaysia and Indonesia.

\section{Results and discussions}

Zaaba \& Hassan (2019) examined the MM Home Financing product's application as practised by two Islamic banks in Malaysia. It further highlighted numerous issues and challenges faced during this implementation. Notably, this research found a gap between the literature review and empirical findings on MM Home Financing; the reasons for the biggest Islamic bank in Malaysia to stop offering MM were its other operational aspects such as refinance issue and marketing reasons. However, one similar issue was found in the literature review and empirical findings, namely the issue of advance rental that needs to be returned to the customer Musharakah Mutanaqisah for Home Financing: The Case of Malaysian Islamic Banks the house is abandoned.

Zaaba \& Hassan (2019) research also contributed significantly with its empirical findings compared to other previous studies. It is hoped that this research will provide new insights to promote further MM Home Financing in Malaysian Islamic banks in specific, and globally in general. More Islamic banks are urged to adopt MM Home Financing to benefit the clients and to ensure its conformity with the Shariah principles. However, few legal rules related to Islamic banking contracts, ownership, pricing mechanism, and other aspects need to be modified to implement MM effectively. Moreover, it is hoped that there would be continuous attempts to improve the facility in the future, and eventually, the reliance on equity financing would increase due to the inherent benefits associated with it and to avoid concentration

Kuwait Finance House Malaysia Berhad first introduced Musharakah Mutanaqisah in Malaysia in 2005 (Nor et al., 2019). Musharakah Mutanaqisah is a contract used to finance property in Malaysia. Musharakah Mutanaqisah is a contract based on the concept of diminishing or decreasing partnership. First, the customer enters into a partnership (Musharakah) under a shirkah al-milk (joint ownership) joint ownership agreement of the assets that both parties have purchased (Meera \& Razak, 2009). Second, the lease system in the ownership of assets to customers is based on the concept of ijarah. Although theoretically, Musharakah Mutanaqisah is an alternative to property financing in Malaysia, in its implementation, both in the retail and commercial context, Musharakah Mutanaqisah in Malaysia is quite problematic. Third, the percentage between the customer and the bank is $20 \%$ and 
$80 \%$; then the customer gradually buys the bank's ownership with the agreed portion until the customer fully owns the asset. The amount of rent between the bank and the customer changes periodically according to the percentage of share ownership owned by both (Meera \& Razak, 2009).

In its implementation, Musharakah Mutanaqisah in general has been used for two properties, namely houses that are ready to be occupied and houses that are still under construction. There are two methods; the first is a property registration procedure, that customer registered as a property owner. Second, the bank is registered as a trustee for the bank and customers (Haneef et al., 2011). Then slowly, bank ownership will decrease and customer ownership will increase, due to the customer's regular purchases until the house is fully owned by the customer (Smolo \& Kabir Hassan, 2011). In the accounting aspect, the practice of Musharakah Mutanaqisah currently has two accepted accounting standards, namely International Financial Reporting Standards (IFRS), issued by the International Accounting Standards Board (IASB), and Financial Accounting Standards (FAS) issued by the International Accounting Standard Board ( AAOIFI). ISRA (2013) shows that the underlying accounting principles, namely substance over form, materiality, fair value and probability principles are consistent with sharia principles. Therefore for current accounting practices, IFRS is considered relevant in Islamic financial transaction accounting (Muhamad Sori, 2017).

Based on this argument, the Central Bank has created a regulation requiring all Islamic financial institutions to prepare and publish their financial reports in accordance with the Malaysian Financial Reporting Standards (MFRS), the local version of IFRS, with the effect of 30 principles based on standards. allows readiness to implement them according to the nature of Islamic contracts and transactions (Muhamad Sori, 2017). A number of local and foreign banks and Malaysian financial institutions offer Musharakah Mutanaqisah as a financing product for each property to attract a variety of customers, both local and international, for both Muslims and non-Muslims (Nor et al., 2019). Although Musharakah Mutanaqisah is one of the alternatives available in the market. However, in its application, the concept of Musharakah Mutanaqisah raises several controversial elements, such as the guarantee and capital protection elements which are considered contrary to the essence of the partnership contract (Naim, 2015). In Malaysia there are several practical problems in the operation of this financing model. The operation of these contracts in Islamic banks is considered to be more likely to approach conventional bank practices, so that the development is less rapid. In addition, the sharia principles that should be the rules could be responsible for maintaining the gate of sharia compliance seemingly unaware of non-compliance in this contract.(Asadov et al., 2018).

Table 1. Malaysian Banking Register

\begin{tabular}{|c|c|c|}
\hline Bank name & Product & Uses \\
\hline RHB Islamic Bank & Equity Home Financing-i works & Home Financing \\
\hline Maybank Islamic & Home Equity-i & Home Financing \\
\hline $\begin{array}{c}\text { Kuwait Finance House } \\
\text { (KFHMB) }\end{array}$ & $\begin{array}{c}\text { Musharakah Mutanaqisah Home } \\
\text { Financing }\end{array}$ & Home Financing \\
\hline OCBC Al-Amin & Property Financing & Home Financing \\
\hline Citibank & Home Partner & Home Financing \\
\hline
\end{tabular}

Source: (Naim, 2015)

\section{Implementation of Musharakah Mutanaqisah Financing in Indonesia}

Based on the discussion, it can be concluded that the law of the Musharakah Mutanaqisah contract is allowed and can be practised in financial institutions in the form of Islamic banks. The application of the Musharakah Mutanaqisah contract by Islamic banks can be realized in-home financing products or what is commonly known in the community is homeownership credit (KPR). Particularly for Islamic banks in Indonesia, in offering home ownership financing, not many use this contract. However, many still use the Murabahah contract and/or the Ijarah Muntahiya Bi Tamlik contract. As for the Islamic banks that have implemented this contract, only the State Savings Bank (BTN Syariah) is also an Islamic bank which is in the status of a Business Unit of a commercial bank.

The current people's attractiveness towards Islamic banking has increased; this has encouraged Islamic banking to continue to develop and innovate products (Husein, 2019). One way to increase the market share (market share) of Islamic banking in Indonesia is by creating Islamic banking products 
that are considered more varied and competitive. One of the Islamic banking products that is considered to have the opportunity to be widely used in Islamic banking in Indonesia (Ridwan \& Syahruddin, $\underline{2013)}$.

In Musharakah financing, including Musharakah Mutanaqisah (MMQ), it was recorded that it only had a share of $28.50 \%$ in December 2015 of total bank financing sharia (Basyariah, 2018). In Indonesia, Musharakah Mutanaqisah is used for Islamic banking products, namely Sharia Home Ownership Credit (KPR Syariah). The Musharakah Mutanaqisah product is considered an alternative to Murabahah financing. So far, the KPR product uses more of the Murabahah contract, so Musharakah Mutanaqisah is an alternative to financing homeownership loans because the Murabahah contract is considered unsuitable be applied in house financing that has a long term (Balgis, 2017).

From the results of the author's search through the website at each bank, namely at 14 Islamic commercial banks in Indonesia, there are only 7 sharia commercial banks that use the Musharakah Mutanaqisah contract, namely: Bank Muamalat Indonesia, BNI Syariah, BTN Syariah, Panin Bank Syariah, Maybank Syariah, Permata Bank Syariah, Panin Bank Syariah.

The iB Muamalat KPR financing product with the Musharakah Mutanaqisah contract is a residential financing facility in accordance with sharia principles. This financing is based on the principle of profit-sharing and is far from usury, because all transactions are carried out transparently to customers. All terms and conditions have been explained at the beginning of the contract, so there will be no objection later when the contract has been implemented (Rohmi, 2015).

In accounting, there have been no regulations governing the accounting for Musharakah Mutanaqisah, and there are no specific regulations in the PSAK that regulate the Musharakah Mutanaqisah contract. The Musharakah Mutanaqisah contract still refers to the Musharakah contract (Sarwedhie \& Suprayogi, 2013). However, PSAK No. 106 which regulates the Musharakah Mutanaqisah can be used as a reference in the Musharakah Mutanaqisah contract's accounting treatment. Because as is well known that the Musharakah contract is a derivative of the Musharakah contract (Balgis, 2017).

In PSAK No. 106 states that the accounting treatment for Musharakah Mutanaqisah includes recognition and measurement, presentation and disclosure. Based on PSAK No. When a Musharakah contract occurs, the capital investment can be in the form of cash and non-cash. When the Musharakah Mutanaqisah contract occurs, the house is owned by both parties, namely the bank and the customer. This is because the house's purchase is based on a combination of capital from the bank and the customer.In the application of Musharakah Mutanaqisah accounting using the subtance over form principle used in the Islamic PSAK, the purchase of a house can be recognized as a transfer of capital in the form of cash or assets (Sarwedhie \& Suprayogi, 2013).

Musharakah Mutanaqisah is a derivative of the Musharakah contract and the procedure is almost the same as the ijarah gagia bittamlik contract (Rohmi, 2015). In the procedure for applying for KPR financing with the Musharakah Mutanaqisah contract, one of which is implemented by the Muamalat bank in the KPR Muamalat iB product, there are three aspects that must be considered (Rohmi, 2015):

a) Customer criteria: The age limit for submitting financing is a minimum age of 21 when applying for financing, a maximum of 55 years for employees, and 60 years as self-employed at the end of the period.

b) $5 \mathrm{C}$ analysis, this analysis is conducted to determine customers' ability and character to make financing, which includes: Character, Capital, Capacity, Condition of Economic, and Collateral.

c) Scoring is a customer assessment based on the data that has been collected. Scoring is also the end of the assessment that determines whether a customer is accepted or not.

Table 2. List of Indonesian Sharia Banking

\begin{tabular}{|c|c|c|}
\hline Bank name & Product name & Akad Used \\
\hline Bank Muamalat Indonesia & KPR iB Muamalat & $\begin{array}{c}\text { Murabahah and Musharakah } \\
\text { Mutanaqisah }\end{array}$ \\
\hline BNI Syariah & Griya iB Khasanah & $\begin{array}{c}\text { Murabahah and Musharakah } \\
\text { Mutanaqisah }\end{array}$ \\
\hline BTN Syariah & Property Financing BTN iB & Musharakah Mutanaqisah \\
\hline
\end{tabular}

2021 | Bukhori: Kajian Ekonomi dan Keuangan Islam/Vol 1 No 1, 1-10 


\begin{tabular}{|c|c|c|}
\hline Bank name & Product name & Akad Used \\
\hline Bank Mega Syariah & Property Ownership & $\begin{array}{c}\text { Murabahah and Musharakah } \\
\text { Financing (SM Griya) }\end{array}$ \\
\hline Panin Syariah Bank & $\begin{array}{c}\text { Panin PaS iB Home } \\
\text { Ownership }\end{array}$ & Musharakah Mutanaqisah \\
& Maybank KPR iB & Musharakah Mutanqisah \\
\hline Maybank Syariah & Permata KPR iB & Musharakah Mutanaqisah \\
\hline Permata Bank Syariah &
\end{tabular}

Source: Each bank's website

Sharia bank product development using the Musharakah Mutanaqisah contract needs to be encouraged. Public understanding and knowledge about the contract which has a foreign category needs to be considered again. Through various events such as Focus Group Discussion, seminars, and socialization to writing articles, this can be a means of conveying knowledge and understanding to the community. If this continues, the development of homeownership products will increase (OJK, 2016).

Table 3. Main Differences in the Application of MMQ in Indonesia and Malaysia

\begin{tabular}{|c|c|c|}
\hline Difference & Indonesia & Malaysia \\
\hline $\begin{array}{c}\text { MMQ Financing } \\
\text { Application Mechanism }\end{array}$ & $\begin{array}{l}\text { 1. The bank and the } \\
\text { customer negotiate on } \\
\text { installments and leases. } \\
\text { 2. Both parties entered into } \\
\text { the MMQ contract. } \\
\text { 3. Bank / Customer buys } \\
\text { goods (house). } \\
\text { 4. Banks and customers } \\
\text { receive important files } \\
\text { and documents. } \\
\text { 5. The customer pays rental } \\
\text { installments. } \\
\text { 6. Islamic banks give up } \\
\text { their ownership rights. } \\
\text { (Hosen, 2016). }\end{array}$ & $\begin{array}{l}\text { 1. Both parties (the customer } \\
\text { and the bank) collaborate } \\
\text { to buy a property or house. } \\
\text { 2. Property/house becomes } \\
\text { joint property between the } \\
\text { bank and the customer. } \\
\text { 3. The customer pays the } \\
\text { rent to the bank for a } \\
\text { predetermined period of } \\
\text { time } \\
\text { 4. The customer gradually } \\
\text { purchased the } \\
\text { homeownership owned by } \\
\text { the bank during that } \\
\text { period. } \\
\text { 5. The portion of bank } \\
\text { ownership is entirely } \\
\text { transferred to the } \\
\text { customer. } \\
\text { (Asadov et al., 2018). }\end{array}$ \\
\hline $\begin{array}{l}\text { Accounting Standards } \\
\text { Used }\end{array}$ & $\begin{array}{l}\text { Referring to PSAK No. } 106 \\
\text { concerning Musharakah } \\
\text { Accounting } \\
\text { (Sarwedhie \& Suprayogi, 2013). }\end{array}$ & $\begin{array}{l}\text { Accounting standards that have } \\
\text { been implemented in Malaysia, } \\
\text { namely Malaysian Financial } \\
\text { Reporting Standards (MFRS) } \\
\text { (Muhamad Sori, 2017). }\end{array}$ \\
\hline Financing Products & $\begin{array}{l}\text { Home / property financing ready } \\
\text { for occupancy. }\end{array}$ & $\begin{array}{l}\text { Home / property financing, both } \\
\text { ready for habitation and still } \\
\text { under construction. }\end{array}$ \\
\hline Problem & $\begin{array}{l}\text { Take over financing, tax issues, } \\
\text { contac hybrids (i.e. there is a sale } \\
\text { and purchase contract in the } \\
\text { MMQ contract). }\end{array}$ & $\begin{array}{l}\text { Considered to tend to approach } \\
\text { conventional financing, } \\
\text { protection and capital } \\
\text { guarantees. } \\
\end{array}$ \\
\hline
\end{tabular}

Source: Author Processed Data

The implementation of Musharakah Mutanaqisah is widely applied in Malaysia. In Indonesia, the contract's use is still rarely implemented, so only a few Islamic banks have implemented it. 
Musharakah Mutanaqisah financing is widely used to finance homeownership. Musharaka mutanaqisah financing is not only applied in Malaysia and Indonesia but also in various countries including: Middle East, United States, Pakistan, Australia (Smolo \& Kabir Hassan, 2011).

This financing is defined as alternative financing for homeownership financing. The financing that is often applied to homeownership financing is Murabahah, Bai Bithaman Ajil, and Ijarah. Musharakah Mutanaqisah is used as a better alternative for financing that has a longer time, making house prices more expensive (Balgis, 2017). Financing property using Musharakah Mutanaqisah is considered to have less risk than other financings (Asadov et al., 2018).

The procedures submitted by customers to banks in financing housing or property loans in Malaysia or Indonesia are quite different. In Malaysia, applying for Musharakah Mutanaqisah financing is easier, the customer must be registered as the property owner, and the bank as the trustee, both for the customer and the bank itself (Haneef et al., 2011). In Indonesia, especially at Bank Muamalat, in its submission, there are several criteria and only customers who have met the criteria can pay for homeownership using the Musharakah Mutanaqisah contract, namely by using the 5C analysis in the criteria for selecting customers (Rohmi, 2015).

In the accounting aspect in general and worldwide, the accounting standard for Musharakah Mutanaqisah refers to IFRS and FAS and the principles used are substance over form. The accounting aspect follows the standards in each country. The accounting aspect and the legal aspect follow the existing regulations in the country. In Malaysia itself, the accounting aspect for regulating Musharakah Mutanaqisah is regulated in an accounting standard that has been applied in Malaysia, namely the Malaysian Financial Reporting Standard (MFRS) (Muhamad Sori, 2017). In Indonesia, the accounting aspects used as a reference for Musharakah Mutanaqisah still refer to PSAK No. 106 which regulates the Musharakah contract (Sarwedhie \& Suprayogi, 2013).

The implementation of Musharakah Mutanaqisah financing in both Malaysia and Indonesia still needs to be encouraged, because it is still not widely applied in banking, both in Indonesia and Malaysia. In its development, this financing is less well known in the community, so that people prefer to use other financings such as Murabahah, Ba'i, ijarah and others (Balgis, 2017).

In Malaysia, Musharakah Mutanaqisah experiences many problems compared to Indonesia, such as the problem of guarantee and capital protection. In practice, this financing is considered more inclined and closer to conventional bank financing where there is still an element of usury. In its implementation it is deemed to deviate from sharia principles (Asadov et al., 2018). Unlike Indonesia, this financing has its own problems, especially related to take-over financing, tax issues, and multicontracts, namely the sale and purchase agreement (Ba'i) in the Musharakah Mutanaqisah contract (Ridwan \& Syahruddin, 2013).

\section{Conclusion}

Musharakah Mutanaqisah is a contract based on the concept of diminishing or decreasing partnership. Musharakah Mutanaqisah financing is a new product in sharia banking that is used for property financing in several countries, including Malaysia and Indonesia. The implementation of Musharakah Mutanaqisah in these two countries still needs to be encouraged for its development, because it is still dominated by Murabahah, Ba'i, ijarah and other financing.

The implementation of Musharakah Mutanaqisah is both an alternative in property financing in Malaysia and home ownership loans in Indonesia. However, in Malaysia, property financing is divided into two, namely for property under construction and ready-to-live houses. In contrast to Indonesia, most homeownership financing with the Musharakah Mutanaqisah contract is used as a ready-to-live house.

The aspects that regulate the accounting treatment of Musharakah Mutanaqisah in Malaysia and Indonesia are very different. However, internationally the accounting for Musharakah Mutanaqisah refers to IFRS and FAS. In Malaysia the regulations governing the accounting of Musharakah Mutanaqisah are regulated in Malaysian Financial Reporting Standards (MFRS). In Indonesia, the regulations governing the accounting for Musharakah Mutanaqisah are not yet available, so they are still regulated in PSAK No. 106 (Musharakah Akad). 


\section{References}

Asadov, A., Muhamad Sori, Z. Bin, Mohamad Ramadilli, S., Anwer, Z., \& Shamsudheen, S. V. (2018). Musharakah Mutanaqisah home financing: issues in practice. Journal of Islamic Accounting and Business Research, 9(1), 91-103. https://doi.org/10.1108/JIABR-08-2015-0036

Balgis, P. D. (2017). Akad Musharakah Mutanaqisa: inovasi baru produk pembiayaan bank syariah. JESI (Jurnal Ekonomi Syariah Indonesia), 7(1), 14. https://doi.org/10.21927/jesi.2017.7(1).14-21

Basyariah, N. (2018). Analisis implementasi pembiayaan Musharakah Mutanaqisah pada perbankan syariah di Indonesia. Muqtasid: Jurnal Ekonomi dan Perbankan Syariah, 9(2), 120. https://doi.org/10.18326/muqtasid.v9i2.120-133

Haneef, R., Kunhibava, S., \& Smolo, E. (2011). Musharakah Mutanaqisah and legal issues: Case study of Malaysia. ISRA International Journal of Islamic Finance, 3(1), 91-122.

Hendarsyah, D. F., Pengaturan, D., Perizinan, D. A. N., \& Syariah, P. (n.d.). Peluang dan tantangan akuntansi Syariah.

Hosen, M. N. (2016). Musharakah Mutanaqisah. Al-Iqtishad: Journal of Islamic Economics, 1(2). https://doi.org/10.15408/aiq.v1i2.2463

Husein, M. T. (2019). Telaah kritis akad Musharakah Mutanaqisah. Al Maal: Journal of Islamic Economics and Banking, 1(1), 79. https://doi.org/10.31000/almaal.v1i1.1775

Ikatan Akuntan Indonesia. (2007). PSAK No.106. DSAK Standar Akuntansi Keuangan.

Loke, K., Wei, K., Mohd, H., \& Thaker, T. (2017). A qualitative inquiry into Islamic home fi nancing: evidence from Malaysia. 9(2), 147-167. https://doi.org/10.1108/QRFM-07-2016-0020

Maulida, S. (2020). Implementasi Akad Pembiayaan Qard dan Wakalah bil Ujrah pada platform fintech lending syariah ditinjau berdasarkan peraturan Otoritas Jasa Keuangan ( OJK ) dan Fatwa DSNMUI. 5(2), 175-189.

Meera, A. K. M., \& Razak, D. A. (2009). Home financing through the Musharakah Mutanaqisah contracts: Some practical issues. Journal of King Abdulaziz University, Islamic Economics, 1, 325. https://doi.org/10.4197/Islec.22-1.1

Muhamad Sori, Z. (2017). Accounting for Musharakah Mutanaqisah home financing: The Malaysia Case. SSRN Electronic Journal, M, 0-17. https://doi.org/10.2139/ssrn.2806947

Naim, A. M. (2015). Purchase undertaking issues. 3(1), 25-48.

Nor, M. Z. M., Mohamad, A. M., Azhar, A., Latif, H. M., Khalid, A. H. M., \& Yusof, Y. (2019). Legal challenges of Musharakah Mutanaqisah as an alternative for property financing in Malaysia. Journal of Legal, Ethical and Regulatory Issues, 22(3).

OJK. (2016). Standar Produk Buku 1: Musharakah Buku 2: Musharakah Mutanaqisah.

Ridwan, M., \& -, S. (2013). Implementasi Musharakah Mutanaqisah sebagai alternatif pembiayaan Murabahah di perbankan Syariah Indonesia. Tsaqafah, 9(1), 101. https://doi.org/10.21111/tsaqafah.v9i1.39

Rohmi, P. K. (2015). Implementasi Akad Musharakah Mutanaqisah pada pembiayaan kepemilikan rumah di bank Muamalat Lumajang. Iqtishoduna, 5(1), 17-37. http://ejurnal.iaisyarifuddin.ac.id/index.php/ekonomiislam/article/view/23

Sabri, S. R. M., \& Ahmad, F. S. (2014). The behaviour of profit of Musharakah Mutanaqisah partnership home ownership by the case of abandoned housing project. AIP Conference Proceedings, 1605, 1067-1072. https://doi.org/10.1063/1.4887739

Sarwedhie, A. K., \& Suprayogi, N. (2013). Perlakuan akuntansi akad Musharakah Mutanaqisah (Studi Kasus: KPR iB pada Bank Muuamalat abang Darmo Surabaya). Journal Article, KPR iB Pada Bank Muamalat Cabang Darmo Surabaya, 428-441. http://download.portalgaruda.org/article.php?article=361290\&val=8147\&title=Perlakuan Akuntansi Akad Musharakah Mutanaqisah (Studi Kasus : KPR iB Pada Bank Muamalat Cabang Darmo Surabaya).

Smolo, E., \& Kabir Hassan, M. (2011). The potentials of mushārakah mutanāqisah for Islamic housing finance. International Journal of Islamic and Middle Eastern Finance and Management, 4(3), 237258. https://doi.org/10.1108/17538391111166476

Undang-undang Republik Indonesia Nomor 18 tahun 2000 tentang pajak pertambahan nilai barang dan jasa dan pajak penjualan atas barang mewah

Waluyo. (2014). Fiqh Muamalah. CV. Gerbang Media. 
Zaaba, Nurul Iffah Binti M A \& Hassan, Rusni (2019). Why Islamic banks are reluctant to offer Musharakah Mutanaqisah for home financing: the case of Maybank Islamic and Affin Islamic Bank. Turkish Journal of Islamic Economics, 6(1). 